\title{
Influences of temperature and water stress on germination of plains rough fescue
}

\author{
J.T. ROMO, P.L. GRILZ, C.J. BUBAR, AND J.A. YOUNG
}

\section{Abstract}

Germination of 12 collections of plains rough fescue (Festuca altaica Trin. subsp. hallii (Vasey) Harms) from Saskatchewan was evaluated in 55 constant and alternating temperature regimes ranging from 0 to $40^{\circ} \mathrm{C}$. Combined influences of temperature and water stress on germination were studied by incubating seeds in a gradient of osmotic potentials at constant temperatures of 5, 10, 15,20 , and $25^{\circ} \mathrm{C}$ and under regimes where temperatures were either increased from 10 to $25^{\circ} \mathrm{C}$ or decreased from 25 to $10^{\circ} \mathrm{C}$. Seeds germinated in 80 to $87 \%$ of the 55 temperature regimes tested with maximum total germination between populations ranging from 34 to $100 \%$. Germination was highest most often at constant temperatures of 15 and $20^{\circ} \mathrm{C}$, but seeds germinated over a wide range of temperatures. Germination rate and total germination responded to the interacting effects of temperature and osmotic potential. Under constant temperatures, 71 to $88 \%$ of the variation in germination was accounted for by osmotic potential. Seeds germinated fastest, in the highest numbers, and over the broadest range of osmotic potentials at 10 to $20^{\circ} \mathrm{C}$. Germination was higher and more rapid over the range of osmotic potentials when temperatures increased from 10 to $25^{\circ} \mathrm{C}$ than when they declined from 25 to $10^{\circ} \mathrm{C}$. Osmotic potential accounted for 65 to $74 \%$ of the variation in germination. The plastic response of germination to temperature suggested that while this factor does not limit regeneration of plains rough fescue from seed, germination is severely restricted by declining osmotic potentials. These moisture limitations reflected adaptations that preclude germination under conditions of transient moisture or low moisture availability. Plains rough fescue should be planted in the spring when temperatures are rising and soil moisture is highest.

Key Words: seedbed ecology, water stress, Festuca altaica subsp. hallii, temperature variation, reproduction, degree days

Plains rough fescue (Festuca altaica Trin. subsp. hallii (Vasey) Harms), (Harms 1985) is the sole dominant of the Fescue Prairie of central Saskatchewan and Alberta (Coupland and Brayshaw 1953, Coupland 1961). There is a paucity of information describing the germination ecology of this perennial. This lack of knowledge stems from the fact that this grass infrequently produces seed (Johnston and MacDonald 1967, Toynbee 1987) and that most of the Fescue Prairie has been severely disturbed by agricultural activities. Johnston and MacDonald (1967) reported that the closely allied rough fescue (Festuca altaica Trin. subsp. scabrella (Torrey) Hulten) produced abundant seed in only 4 years during a 65-year period in Alberta. In Saskatchewan a copious seed crop was produced by plains rough fescue in 1987 (Toynbee 1987), affording an excellent opportunity to study its germination requirements.

\footnotetext{
Authors are associate professor and graduate research assistants, Department of Crop Science and Plant Ecology, University of Saskatchewn, Saskatoon, S7N, 0W0; and range scientist, USDA-ARS, Reno, Nevada 89512.

This paper is dedicated to the memory of Alexander Johnston, who spent most of his career studying the native flora of the Fescue Prairie in the foothills of Alberta. His research provided a foundation for our understanding of the ecology of Fescue Prairie.

The authors thank Drs. L.E. Eddleman, R. Horton, R.E. Redmann, and A. Schwarz for manuscript reviews.

Manuscript accepted 18 May 1990.
}

Objectives of this study were to: 1 . characterize germinationtemperature relationships for several collections of plains rough fescue from Saskatchewan, and 2. identify its germination response to various temperatures and osmotic potentials. This information will assist those charged with developing strategies for reestablishing and managing Fescue Prairie.

\section{Materials and Methods}

Three germination experiments were conducted. Germination of 12 collections of plains rough fescue from Saskatchewan was evaluated in 55 constant and alternating temperature regimes ranging from 0 to $40^{\circ} \mathrm{C}$ in the first experiment. In the second experiment seeds of 8 collections were incubated at $5,10,15,20$, and $25^{\circ}$ $\mathrm{C}$ in a gradient of osmotic potentials that was created by using polyethylene glycol (PEG) to depress osmotic potentials. Eight collections were evaluated in the third experiment, which was designed to evaluate germination response under various osmotic potentials when temperatures were either increased from 10 to $25^{\circ}$ $\mathrm{C}$ or reduced from 25 to $10^{\circ} \mathrm{C}$.

Seeds of plains rough fescue were collected in Saskatchewan at 8 sites in 1987 and 4 sites in 1988 (Table 1). Seed production was

Table 1. Locations and descriptions of sites where plains rough feseue seed was collected in Saskatchewan.

\begin{tabular}{|c|c|c|}
\hline Site & $\begin{array}{l}\text { Legal } \\
\text { Description }\end{array}$ & $\begin{array}{l}\text { Associated } \\
\text { Vegetation }\end{array}$ \\
\hline $\begin{array}{l}\text { Strawberry Hills } \\
\text { West Allan Hills } \\
\text { East Allan Hills } \\
\text { Biddulph Prairie } \\
\text { Pinto Butte } \\
\text { Radisson } \\
\text { Sonningdale } \\
\text { Cypress Hills }\end{array}$ & $\begin{array}{l}987-\ldots \\
\text { T37,R4,Sec.12,W3 } \\
\text { T31,R3,Sec.21,W3 } \\
\text { T31,R1,Sec.15,W3 } \\
\text { T34,R6,Sec.12,W3 } \\
\text { T5,R12,Sec.13,W3 } \\
\text { T39,R10,Sec.29,W3 } \\
\text { T40,R12,Sec.32,W3 } \\
\text { T8,R29,Sec.9,W3 }\end{array}$ & $\begin{array}{l}\text { Potr', Elco } \\
\text { Potr, Elco } \\
\text { Potr, Elco } \\
\text { Stco, Stsp, Agda } \\
\text { Agda, Stsp, Syoc } \\
\text { Potr, Elco, Agda } \\
\text { Potr, Elco, Stsp, Agda } \\
\text { Potr, Pofr, Dain }\end{array}$ \\
\hline $\begin{array}{l}\text { Sonningdale } \\
\text { Cypress Hills } \\
\text { Wood Mountain } \\
\text { Eagle Hills }\end{array}$ & $\begin{array}{l}988 \\
\text { T40,R12,Sec.32,W3 } \\
\text { T8,R29,Sec.15,W3 } \\
\text { T4,R3,Sec.12,W3 } \\
\text { T41,R16,Sec.26,W3 }\end{array}$ & $\begin{array}{l}\text { Potr, Elco, Stsp, Agda } \\
\text { Agtr, Potr, Pofr, Dain } \\
\text { Pofr, Agda, Stsp } \\
\text { Potr, Stsp }\end{array}$ \\
\hline
\end{tabular}

${ }^{\prime}$ Potr $=$ Populus tremuloides, Elco = Eleagnus commutata, Stco $=$ Stipa comata, Stsp $=$ Stipa spartea var. curtiseta, Agtr = Agropyron trachycaulum, Agda $=$ Agropyron dasytachyum, Pofr = Potentilla fruticosa, Dain = Danthonia intermedia, Syoc = Symphoricarpos occidentalis

extremely poor in 1988 , thus we were able to repeat collections again only from the Sonningdale and Cypress Hills locations. No seeds were produced at any of the sites in 1989. After seeds were collected, they were taken to the laboratory, cleaned, and stored in paper envelopes in darkness at room temperature. Germination tests were conducted 4 to 6 months following collection.

Experiment 1-Influence of 55 Constant and Alternating Temperature Regimes on Germination

Twenty-five seeds were placed in each closed petri dish on $1 \mathrm{~mm}$ thick germination paper that was kept moist with water, and incubated at 4 weeks in dark germinators at 55 constant and 
alternating temperatures. Alternating temperature regimes consisted of a 16-hour cold period and an 8-hour warm period, at all possible higher temperatures in each 24 -hour interval. For example, $2^{\circ} \mathrm{C}$ (cold period) was alternated with $5,10,15,20,25,30,35$, and $40^{\circ} \mathrm{C}$ (warm period), whereas $25^{\circ} \mathrm{C}$ (cold period) alternated only with 30,35 , and $40^{\circ} \mathrm{C}$ (warm period). Germination was recorded after 1, 2, and 4 weeks of incubation; seeds were considered germinated when the radicle was at least $5 \mathrm{~mm}$ long. A randomized complete block design with 4 replications was used.

Germination parameters from the temperature-germination regression equations are defined as: 1 . Mean germination-the average germination of the 55 temperatures regimes; 2 . Mean of regimes with some germination (regimes with $0 \%$ germination are excluded); 3. Percentage with some germination-the percentage of the 55 temperature regimes in which some seeds germinated; 4. Maximum-the highest germination of the 55 temperature regimes; 5 . Maximum mean-the average germination of the temperature regimes with maximum germination, and; 6 . Percentage with maximum germination - the percentage of the 55 temperature regimes with germination not lower than the maximum germination minus one-half its $95 \%$ confidence interval. The frequency of maximum is the percentage of the time that each temperature regime supports maximum germination. This value is determined across the collections, providing an estimate of the optimum temperatures for germination. Details of the statistical procedures provided by Evans et al. (1982).

\section{Procedures Used for Experiments 2 and 3}

Ecological interpretation of many germination experiments is difficult because tests are conducted for specific periods of time over a range of temperatures. These arbitrary incubation periods introduce time as a confounding factor because seeds are not receiving equal thermal units at all temperatures. Therefore, in Experiments 2 and 3 the length of incubation periods was based on a set number of degree days using $0^{\circ} \mathrm{C}$ as the base temperature. This was done because germination is a temperature-sensitive process, and the use of degree days integrates both time and temperature (Johnson and Thornley 1985).

Solutions were prepared to depress osmotic potentials to -0.3 , $-0.6,-0.9,-1.2$, and $-1.5 \mathrm{MPa}$ by adding PEG (M.W. 20,000) to distilled water. Distilled water was used as the control $(0.0 \mathrm{MPa})$.
Osmotic potentials of these PEG solutions were determined with a Wescor vapor pressure osmometer.

A randomized complete block design with 50 seeds in each of 4 replications was used. Seeds were incubated in closed petri dishes on $1 \mathrm{~mm}$ thick germination paper that was moistened by adding 7 $\mathrm{mL}$ of water or PEG solution. These petri dishes were enclosed and sealed in polyethylene bags to prevent desiccation. Germination counts were made at 2-day intervals; a seed was considered germinated when the plumule and radicle were both at least $5 \mathrm{~mm}$ long. Germinated seeds were removed from petri dishes, and after completing the incubation period the ungerminated seeds were dissected to determine if they were filled. Thus, data for Experiments 2 and 3 are expressed as a percentage of florets that actually had fully developed caryopses.

\section{Experiment 2-Constant Temperature-Osmotic Potential Effects on Germination}

Seeds were incubated at $5,10,15,20$, and $25^{\circ} \mathrm{C}$ in darkness for 400 degree days. Mean osmotic potentials and standard errors $(n=4)$ for the PEG solutions used for the 1987 collections were $-0.20 \pm 0.02,-0.50 \pm 0.01,-0.81 \pm 0.02,-0.90 \pm 0.03,-1.17 \pm 0.02$ $\mathrm{MPa}$. They were $-0.29 \pm 0.01,-0.68 \pm 0.02,-0.99 \pm 0.02,-1.27 \pm$ 0.03 , and $-1.64 \pm 0.05 \mathrm{MPa}$ for the 1988 collections. Temperature and osmotic potential treatments were factorially applied within collections.

\section{Experiment 3-Ascending and Descending Temperatures and Os- motic Potential Effects on Germination}

The effects of osmotic potential, and temperatures decreasing from 25 to $10^{\circ} \mathrm{C}$ and increasing from 10 to $25^{\circ} \mathrm{C}$, were studied in Experiment 3. Temperatures were increased or decreased at a rate of $0.5^{\circ} \mathrm{C}$ per day, but the actual change in degree days depended on temperatures. Seeds were incubated for 600 degree days and germination was tallied using the procedures described in Experiment 2. Mean osmotic potentials and standard errors $(n=4)$ were $-0.22 \pm 0.02,-0.71 \pm 0.02,-1.15 \pm 0.05,-1.64 \pm 0.06 \mathrm{MPa}$ for the 1987 collections and $-0.34 \pm 0.01,-0.58 \pm 0.01,-0.78 \pm 0.03$, $-0.95 \pm 0.02$, and $-1.08 \pm 0.04 \mathrm{MPa}$ for the 1988 collections. Within collections the treatments were factorially applied using temperature regimes and osmotic potentials as the main effects.

Table 2. Germination parameters for plains rough fescue seed collected in Saskatchewan and incubated in 55 temperature regimes. See Table 1 for information regarding collections.

\begin{tabular}{|c|c|c|c|c|c|c|c|c|c|c|c|c|}
\hline \multirow[b]{2}{*}{$\begin{array}{l}\text { Germination } \\
\text { parameter }\end{array}$} & \multirow[b]{2}{*}{$\begin{array}{l}\text { Straw- } \\
\text { berry } \\
\text { Hills }\end{array}$} & \multirow[b]{2}{*}{$\begin{array}{l}\text { West } \\
\text { Allan } \\
\text { Hills }\end{array}$} & \multirow[b]{2}{*}{$\begin{array}{c}\text { East } \\
\text { Allan } \\
\text { Hills }\end{array}$} & \multirow[b]{2}{*}{$\begin{array}{l}\text { Biddulph } \\
\text { Prairie }\end{array}$} & \multicolumn{2}{|c|}{ Seed Source } & \multirow[b]{2}{*}{$\begin{array}{l}\text { Sonning- } \\
\text { n dale } \\
1987\end{array}$} & \multirow[b]{2}{*}{$\begin{array}{l}\text { Sonning- } \\
\text { dale } \\
1988\end{array}$} & \multirow[b]{2}{*}{$\begin{array}{c}\text { Cypress } \\
\text { Hills } \\
1987\end{array}$} & \multirow[b]{2}{*}{$\begin{array}{c}\text { Cypress } \\
\text { Hills } \\
1988\end{array}$} & \multirow[b]{2}{*}{$\begin{array}{c}\text { Wood } \\
\text { Mountain }\end{array}$} & \multirow[b]{2}{*}{$\begin{array}{l}\text { Eagle } \\
\text { Hills }\end{array}$} \\
\hline & & & & & $\begin{array}{l}\text { Pinto } \\
\text { Butte }\end{array}$ & Radisson & & & & & & \\
\hline Mean $(\%)^{\prime}$ & 28 & 35 & 31 & 26 & 12 & 36 & 41 & 15 & 17 & 27 & 27 & 27 \\
\hline $\begin{array}{l}\text { Mean with some } \\
\text { germination }(\%)^{2}\end{array}$ & 36 & 42 & 36 & 33 & 14 & 44 & 48 & 18 & 19 & 31 & 32 & 32 \\
\hline $\begin{array}{l}\text { Percentage with } \\
\text { some germination }\end{array}$ & 80 & 84 & 85 & 80 & 84 & 84 & 85 & 85 & 87 & 87 & 84 & 85 \\
\hline $\begin{array}{l}\text { Percentage with } \\
\text { maximum germination }\end{array}$ & 7 & 4 & 7 & 4 & 7 & 5 & 5 & 5 & 13 & 5 & 4 & 4 \\
\hline Maximum Mean $(\%)^{5}$ & 67 & 90 & 73 & 70 & 32 & 86 & 96 & 43 & 36 & 67 & 73 & 74 \\
\hline $\begin{array}{l}\text { Maximum } \\
\text { Germination }(\%)^{6}\end{array}$ & 70 & 92 & 76 & 71 & 34 & 89 & 100 & 45 & 38 & 70 & 74 & 76 \\
\hline $\begin{array}{l}\text { Total Filled } \\
\text { Seed }(\% \pm \text { s.e. })\end{array}$ & $91 \pm 1$ & $98 \pm 1$ & $93 \pm 2$ & $90 \pm 2$ & $65 \pm 5$ & $97 \pm 1$ & $99 \pm 1$ & $76 \pm 4$ & $68 \pm 10$ & $85 \pm 1$ & $84 \pm 4$ & $91 \pm 2$ \\
\hline
\end{tabular}

1 Mean germination is the average germination of the 55 temperature regimes tested.

${ }_{2}^{2}$ Mean of regimes with some germination excluding regimes with no germination.

${ }^{3}$ Percentage with some germination is the percentage of the 55 temperature regimes in which some seeds germinated.

4Percentage with maximum germination is the percentage of the 55 temperature regimes having maximum germination.

sMaximum mean is the average germination of the temperature regimes with maximum germination.

${ }^{6}$ Maximum germination is the highest germination observed in the 55 temperature regimes. 
Data Analyses for Experiments 2 and 3

Since we were not able to collect seeds from plants grown under uniform environmental conditions, it was deemed inappropriate to make comparisons of germination responses among collections because of environmental influences on parent plants. Therefore, after transforming total germination percentage and germination rate (\%/degree day) (Maguire 1962) with arcsin $\sqrt{p}$ each collection was subjected to factorial analysis of variance using temperature or temperature regime and osmotic potentials as main effects (Snedecor and Cochran 1980). Variance components were then estimated from analysis of variance by determining the percentage of the total variation that was accounted for by the main effects and their interactions. The best fit polynomial response curves were then developed for total germination and germination rate in Experiment 3 (Steel and Torrie 1980). All statistical analyses were conducted at the $P \leq 0.05$ probability.

\section{Results}

Influence of 55 Constant and Alternating Temperature Regimes on Germination

Mean total germination over all temperature regimes ranged from a high of $41 \%$ for the 1987 Sonningdale collection to a low of $12 \%$ for the Pinto Butte collection (Table 2). The 1988 Sonningdale collection had the second lowest total germination percentage of the 12 sources tested, showing that large year-to-year variation existed.

Seeds germinated in 80 to $87 \%$ of the temperature regimes tested, with total germination at these temperatures averaging from 14 to $48 \%$ (Table 2). Maximum total germination was $70 \%$ or higher in 9 of the 12 collections tested. Germination was maximum in 4 to $13 \%$ of the regimes with means varying between 32 and $96 \%$.

For the 1987 collections 7 temperature regimes supported maximum germination at least once; it occurred with a frequency of $80 \%$ at $15 / 15$ and $20 / 20^{\circ} \mathrm{C}$ (Table 3 ). These same temperature
Table 3. Frequency of maximum germination for temperature-germination profiles for all collections of plains rough fescue seed collected Saskatchewan.

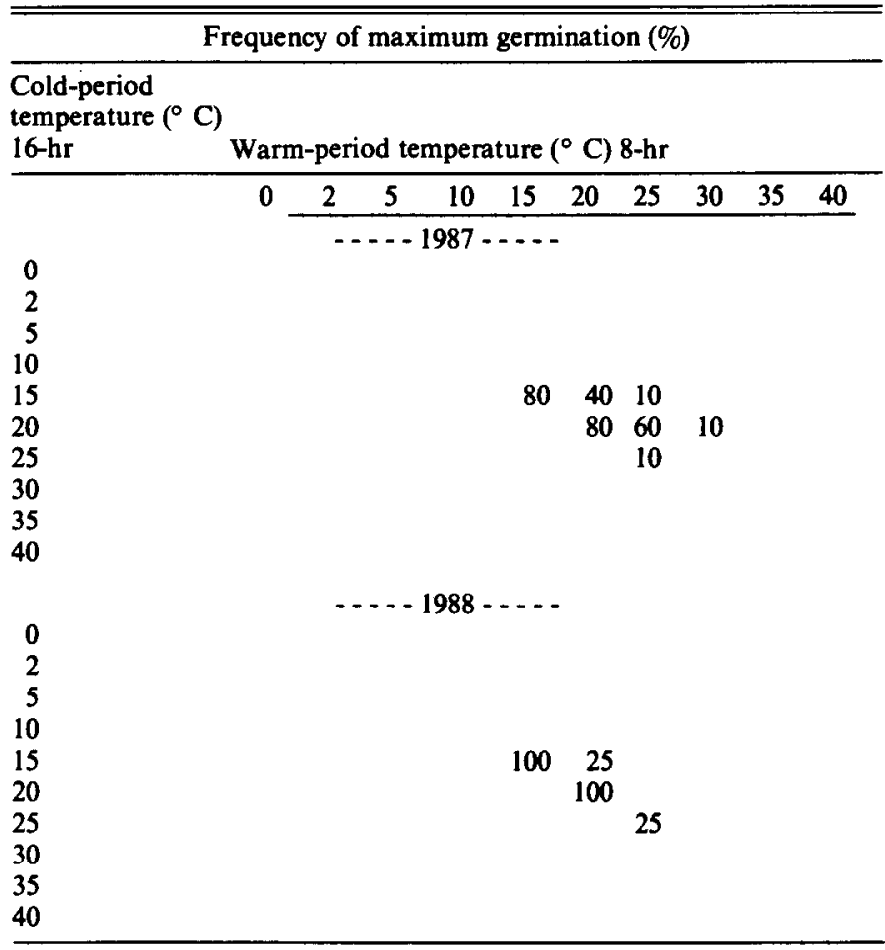

regimes provided optimal conditions for germination of all collections in 1988.

Complete response surfaces are presented for the Cypress Hills and Sonningdale collections made in 1987 and 1988 (Tables 4 and

Table 4. Estimated total germination (\%) and confidence intervals for the 1987 and 1988 Cypress Hills collections of plains rough fescue seeds incubated for 4 weeks in darkness at 55 constant and alternating temperatures.1

\begin{tabular}{|c|c|c|c|c|c|c|c|c|c|c|}
\hline \multirow{2}{*}{$\begin{array}{l}\text { Cold-period } \\
\text { temperature } \\
\text { ( }^{\circ} \text { C) } 16-h r\end{array}$} & \multicolumn{10}{|c|}{ Warm-period temperature $\left({ }^{\circ} \mathrm{C}\right) 8$-hr } \\
\hline & 0 & 2 & 5 & 10 & 15 & 20 & 25 & 30 & 35 & 40 \\
\hline $\begin{array}{r}0 \\
2 \\
5 \\
10 \\
15\end{array}$ & $0(5)$ & $\begin{array}{l}0(4) \\
6(4)\end{array}$ & $\begin{array}{r}1(3) \\
8(3) \\
17(3)\end{array}$ & $\begin{array}{r}2(3) \\
9(2) \\
18(2) \\
29(3)\end{array}$ & $\begin{array}{r}3(3) \\
10(3) \\
18(2) \\
30(2) \\
37(4) \\
\end{array}$ & $\begin{array}{r}3(3) \\
9(3) \\
18(2) \\
29(2) \\
36(3) \\
\end{array}$ & $\begin{array}{r}2(3) \\
8(3) \\
17(2) \\
27(2) \\
34(2) \\
\end{array}$ & $\begin{array}{r}0(3) \\
6(3) \\
15(2) \\
25(2) \\
32(2)\end{array}$ & $\begin{array}{r}0(4) \\
3(3) \\
12(2) \\
22(2) \\
28(3)\end{array}$ & $\begin{array}{r}0(5) \\
0(4) \\
8(4) \\
18(3) \\
24(4)\end{array}$ \\
\hline 25 & & & & & & & $35(4)$ & $32(2)$ & $28(2)$ & 23(4) \\
\hline $\begin{array}{l}30 \\
35 \\
40\end{array}$ & & & & & & & & 26(4) & $\begin{array}{l}22(3) \\
11(4)\end{array}$ & $\begin{array}{r}17(4) \\
6(4) \\
0(6)\end{array}$ \\
\hline $\begin{array}{r}0 \\
2 \\
5 \\
10 \\
15\end{array}$ & $0(7)$ & $\begin{array}{l}0(6) \\
9(6)\end{array}$ & $\begin{array}{r}2(5) \\
13(4) \\
28(5)\end{array}$ & $\begin{array}{r}8(4) \\
19(4) \\
33(3) \\
53(5)\end{array}$ & $\begin{array}{l}11(5) \\
22(4) \\
36(3) \\
54(3) \\
67(5)\end{array}$ & $\begin{array}{l}11(5) \\
21(4) \\
35(3) \\
52(3) \\
64(4) \\
\end{array}$ & $\begin{array}{r}8(5) \\
18(4) \\
31(3) \\
48(3) \\
59(3)\end{array}$ & $\begin{array}{r}3(4) \\
12(4) \\
25(3) \\
41(3) \\
50(3)\end{array}$ & $\begin{array}{r}0(5) \\
3(4) \\
15(3) \\
30(3) \\
39(4)\end{array}$ & $\begin{array}{r}0(8) \\
0(7) \\
3(5) \\
17(5) \\
25(5)\end{array}$ \\
\hline 20 & & & & & & $70(6)$ & 63(4) & $54(3)$ & 42(4) & $27(6)$ \\
\hline $\begin{array}{l}25 \\
30 \\
35 \\
40\end{array}$ & & & & & & & 62(5) & $\begin{array}{l}52(4) \\
44(5)\end{array}$ & $\begin{array}{l}39(4) \\
30(4) \\
15(6)\end{array}$ & $\begin{array}{r}24(5) \\
14(5) \\
0(6) \\
0(9)\end{array}$ \\
\hline
\end{tabular}

IMaximum values are underlined and defined as those values not lower than the maximum minus $1 / 2$ its confidence interval $(P \leq 0.05)$. The values in parentheses are one-half the confidence interval. 
Table 5. Estimated total germination (\%) and confidence intervals for the 1987 and 1988 Sonningdale collections of plains rough fescue seeds incubated for 4 weeks in darkness at 55 constant and alternating temperatures. ${ }^{1}$

\begin{tabular}{|c|c|c|c|c|c|c|c|c|c|c|}
\hline \multirow{2}{*}{$\begin{array}{l}\text { Cold-period } \\
\text { temperature } \\
\left(^{\circ} \mathrm{C}\right) 16-\mathrm{hr}\end{array}$} & \multicolumn{10}{|c|}{ Warm-period temperature $\left({ }^{\circ} \mathrm{C}\right)$ 8-hr } \\
\hline & 0 & 2 & 5 & 10 & 15 & 20 & 25 & 30 & 35 & 40 \\
\hline $\begin{array}{r}0 \\
2 \\
5 \\
10 \\
15\end{array}$ & $O(7)$ & $\begin{array}{r}0(6) \\
12(6)\end{array}$ & $\begin{array}{r}0(5) \\
16(5) \\
40(5)\end{array}$ & $\begin{array}{l}2(5) \\
20(4) \\
44(3) \\
75(5)\end{array}$ & $\begin{array}{r}4(5) \\
21(4) \\
45(3) \\
75(4) \\
95(6) \\
\end{array}$ & $\begin{array}{r}4(5) \\
21(4) \\
44(4) \\
73(4) \\
92(4)\end{array}$ & $\begin{array}{r}1(5) \\
18(4) \\
40(4) \\
69(4) \\
87(4)\end{array}$ & $\begin{array}{r}o(5) \\
13(4) \\
35(3) \\
62(4) \\
79(4)\end{array}$ & $\begin{array}{r}0(6) \\
5(5) \\
27(4) \\
53(4) \\
69(4)\end{array}$ & $\begin{array}{r}0(8) \\
0(7) \\
16(6) \\
42(5) \\
57(6)\end{array}$ \\
\hline 20 & & & & & & $100(6)$ & 94(4) & $86(4)$ & $75(4)$ & $62(6)$ \\
\hline \multirow[t]{2}{*}{$\begin{array}{l}25 \\
30 \\
35 \\
40\end{array}$} & & & & & & & $91(6)$ & $\begin{array}{l}81(4) \\
66(6)\end{array}$ & $\begin{array}{l}70(4) \\
54(4) \\
27(7)\end{array}$ & $\begin{array}{c}56(6) \\
39(6) \\
11(7) \\
0(10)\end{array}$ \\
\hline & $\mathbf{0}$ & 2 & 5 & 10 & 15 & 20 & 25 & 30 & 35 & 40 \\
\hline $\begin{array}{r}0 \\
2 \\
5 \\
10 \\
15\end{array}$ & $0(5)$ & $\begin{array}{l}0(4) \\
3(4)\end{array}$ & $\begin{array}{r}0(3) \\
5(3) \\
16(3)\end{array}$ & $\begin{array}{r}1(3) \\
8(2) \\
18(2) \\
32(3)\end{array}$ & $\begin{array}{r}3(3) \\
10(3) \\
19(2) \\
32(2) \\
42(4) \\
\end{array}$ & $\begin{array}{r}4(3) \\
10(3) \\
18(2) \\
30(2) \\
39(3)\end{array}$ & $\begin{array}{r}3(3) \\
9(3) \\
16(2) \\
27(2) \\
34(2)\end{array}$ & $\begin{array}{r}1(3) \\
6(3) \\
13(2) \\
22(2) \\
28(2)\end{array}$ & $\begin{array}{r}0(4) \\
2(3) \\
8(2) \\
15(2) \\
21(3)\end{array}$ & $\begin{array}{r}0(5) \\
0(4) \\
1(4) \\
8(3) \\
11(4)\end{array}$ \\
\hline 20 & & & & & & $45(4)$ & $39(3)$ & $32(2)$ & $23(3)$ & $12(4)$ \\
\hline 25 & & & & & & & $\underline{41(4)}$ & 32(2) & $22(2)$ & $11(4)$ \\
\hline $\begin{array}{l}30 \\
35 \\
40\end{array}$ & & & & & & & & $31(4)$ & $\begin{array}{l}19(3) \\
13(4)\end{array}$ & $\begin{array}{l}6(4) \\
0(4) \\
0(6)\end{array}$ \\
\hline
\end{tabular}

'Maximum values are underlined and defined as those values not lower than the maximum minus $1 / 2$ its confidence interval ( $P \leq 0.05$ ). The values in parentheses are one-half the confidence interval.

5). These were the only sites where collection was possible in both years. Year-to-year and site-to-site variability are reflected in both sources with the Cypress Hills collection displaying highest total germination and optimal temperatures that were more restricted in 1988 than in 1987. The Sonningdale collection showed a reversed response with highest and lowest total germination in 1987 and 1988, respectively, but the range of optimum temperatures varied little. Much of this variation between collections is attributed to variation in the percentage of filled seeds (Table 2); however, dormancy can not be ruled out as a contributor to some of this variation.

\section{Constant Temperature-Osmotic Potential Effects on Germination}

Germination of all collections was the product of the interacting effects of temperature and osmotic potential. Generally, total germination and germination rate were lowest at 5 and $25^{\circ} \mathrm{C}$ and highest at intermediate temperatures (Tables 6 and 7). Total germination was highest and seeds germinated most rapidly over the broadest range of osmotic potentials at 10 to $20^{\circ} \mathrm{C}$. Over the entire temperature range, germination was severely restricted by declining osmotic potentials; no seeds germinated at osmotic potentials below -0.81 and $-0.99 \mathrm{MPa}$ for the 1987 and 1988 collections, respectively.

Analysis of variance showed that 71 to $88 \%$ of the variation in total germination was accounted for by osmotic potential. The combined effect of temperature and the interacting effects of temperature and osmotic potential accounted for 10 to $23 \%$ of the variation. These variance components implicated water stress as the primary determinant of germination.

\section{Ascending and Descending Temperatures and Osmotic Potential Effects on Germination}

Total percent germination was higher and germination rate more rapid over a broader range of osmotic potentials when incubated under temperatures that were increasing from 10 to $25^{\circ} \mathrm{C}$ than when temperatures declined from 25 to $10^{\circ} \mathrm{C}$ (Fig. la and $1 \mathrm{~b}$ ).

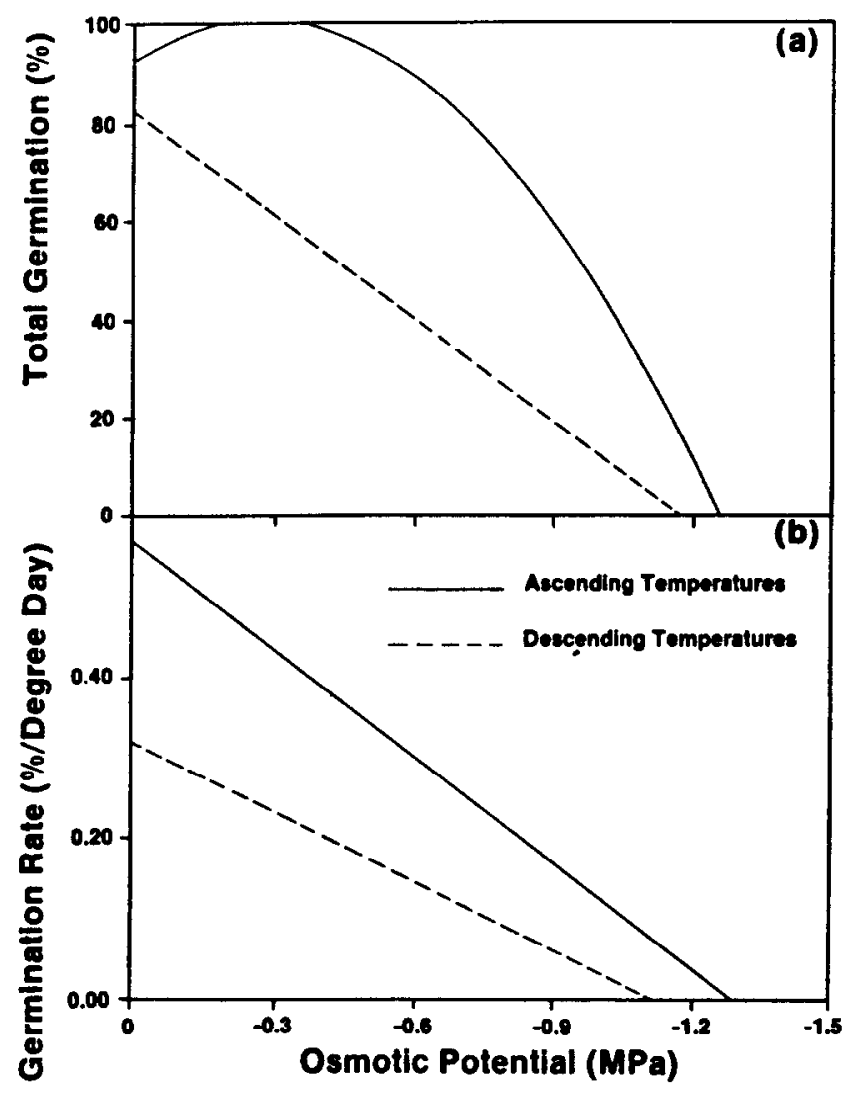

Fig. 1a and 1b. Response curves for (a) total germination and (b) germination rate for the West Allan Hills collection of plains rough fescue incubated in a gradient of osmotic potentials with temperatures ascending from 10 to $25^{\circ} \mathrm{C}$ and descending from 25 to $10^{\circ} \mathrm{C}$. Regression equations for the response curves are presented in Table 8. 
Table 6. Mean total germination (\%) and standard errors for the temperature and oamotic potential interaction for 8 collections of plains rough fescue seed incubated for 400 degree days (base temperature equals $0^{\circ} \mathrm{C}$ ) at temperatures between 5 and $25^{\circ} \mathrm{C}$ in a gradient of osmotic potentials.

\begin{tabular}{|c|c|c|c|c|c|c|}
\hline \multirow{3}{*}{$\begin{array}{l}\text { Osmotic } \\
\text { Potential } \\
\text { (MPa) }\end{array}$} & \multicolumn{6}{|c|}{ Total germination (\%) } \\
\hline & \multicolumn{6}{|c|}{ Temperature $\left({ }^{\circ} \mathrm{C}\right)$} \\
\hline & 5 & 10 & 15 & 20 & 25 & $\begin{array}{c}\text { Standard } \\
\text { error }\end{array}$ \\
\hline & \multicolumn{6}{|c|}{ - } \\
\hline 0.00 & 64.0 & 85.0 & 83.3 & 83.5 & 56.3 & \\
\hline-0.20 & 54.0 & 75.0 & 77.5 & 84.8 & 56.5 & \\
\hline-0.50 & 8.0 & 15.0 & 67.5 & 50.0 & 9.5 & \\
\hline-0.81 & 0.0 & 0.0 & 14.5 & 4.5 & 0.5 & \\
\hline \multirow[t]{2}{*}{-0.90} & 0.0 & 0.0 & 0.0 & 0.0 & 0.0 & 2.9 \\
\hline & \multicolumn{6}{|c|}{ - _ _ _ - Strawberry Hills-1987 _. . . - } \\
\hline 0.00 & 77.0 & 92.0 & 95.0 & 87.5 & 83.0 & \\
\hline-0.20 & 77.5 & 88.0 & 85.0 & 86.5 & 70.5 & \\
\hline-0.50 & 20.5 & 22.0 & 78.5 & 54.8 & 21.0 & \\
\hline-0.81 & 0.0 & 0.0 & 28.0 & 0.5 & 0.5 & \\
\hline \multirow[t]{2}{*}{-0.90} & 0.0 & 0.0 & 0.0 & 0.0 & 0.0 & 2.6 \\
\hline & \multicolumn{6}{|c|}{ - _ . - Radisson-1987 _. . - - } \\
\hline 0.00 & 76.0 & 95.5 & 96.0 & 94.5 & 73.0 & \\
\hline-0.20 & 79.0 & 81.0 & 85.5 & 93.5 & 73.5 & \\
\hline-0.50 & 17.5 & 23.5 & 79.0 & 64.5 & 17.0 & \\
\hline-0.81 & 0.0 & 0.0 & 22.0 & 8.5 & 0.5 & \\
\hline \multirow[t]{2}{*}{-0.90} & 0.0 & 0.0 & 0.0 & 0.0 & 0.0 & 2.3 \\
\hline & \multicolumn{6}{|c|}{$-\ldots$ Allan Hills-1987 $\ldots$} \\
\hline 0.00 & 83.0 & 97.5 & 94.5 & 94.5 & 81.5 & \\
\hline-0.20 & 86.0 & 89.0 & 85.8 & 94.0 & 71.5 & \\
\hline-0.50 & 36.5 & 21.5 & 88.5 & 74.5 & 20.0 & \\
\hline-0.81 & 0.0 & 0.0 & 19.5 & 14.0 & 0.5 & \\
\hline \multirow[t]{2}{*}{-0.90} & 0.0 & 0.0 & 0.0 & 0.0 & 0.0 & 2.2 \\
\hline & \multicolumn{6}{|c|}{ - $\ldots$ - Cypress Hills-1988 } \\
\hline 0.00 & 75.0 & 60.0 & 79.0 & 68.0 & 63.5 & \\
\hline-0.29 & 75.5 & 83.5 & 88.5 & 66.5 & 52.0 & \\
\hline-0.68 & 14.5 & 67.0 & 65.5 & 25.0 & 12.0 & \\
\hline-0.99 & 0.0 & 29.0 & 3.5 & 0.0 & 0.0 & \\
\hline \multirow[t]{2}{*}{-1.27} & 0.0 & 0.0 & 0.0 & 0.0 & 0.0 & 3.9 \\
\hline & \multicolumn{6}{|c|}{ - . . - Wood Mountain-1988 } \\
\hline 0.00 & 69.5 & 80.0 & 77.5 & 80.5 & 75.5 & \\
\hline-0.29 & 46.0 & 85.0 & 77.5 & 69.5 & 60.0 & \\
\hline-0.68 & 4.5 & 61.5 & 60.5 & 43.5 & 13.0 & \\
\hline-0.99 & 0.0 & 12.5 & 0.0 & 0.0 & 0.0 & \\
\hline \multirow[t]{2}{*}{-1.27} & 0.0 & 0.0 & 0.0 & 0.0 & 0.0 & 3.4 \\
\hline & \multicolumn{6}{|c|}{ - . - Sonningdale-1988 } \\
\hline 0.00 & 54.5 & 77.0 & 78.0 & 71.0 & 64.5 & \\
\hline-0.29 & 36.5 & 75.5 & 81.0 & 60.5 & 40.5 & \\
\hline-0.68 & 3.3 & 54.5 & 49.5 & 23.5 & 8.0 & \\
\hline-0.99 & 0.0 & 3.5 & 2.5 & 0.0 & 0.0 & \\
\hline \multirow[t]{2}{*}{-1.27} & 0.0 & 0.0 & 0.0 & 0.0 & 0.0 & 5.1 \\
\hline & \multirow{2}{*}{\multicolumn{6}{|c|}{ 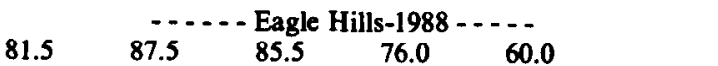 }} \\
\hline 0.00 & & & & & & \\
\hline-0.29 & 61.0 & 86.5 & 68.0 & 70.0 & 70.0 & \\
\hline-0.68 & 5.5 & 74.0 & 63.5 & 28.5 & 17.0 & \\
\hline-0.99 & 0.0 & 13.5 & 0.0 & 0.0 & 0.0 & \\
\hline-1.27 & 0.0 & 0.0 & 0.0 & 0.0 & 0.0 & 3.0 \\
\hline
\end{tabular}

In all cases total germination-osmotic potential relationships were quadratic in the increasing temperature regime; conversely, total germination declined linearly as osmotic potentials declined under the descending temperature regime for all collections (Table 8; Fig. 1a). Whether under the ascending or descending temperature regime, germination rate declined in a linear fashion as osmotic potentials decreased (Table 8; Fig. 1b).

Water stress was the major contributor to variation observed in total germination. Sixty-five to $74 \%$ of the variation in total germi-
Table 7. Mean germination rate (\%/degree day) and standard errors for the temperature and osmotic potential interaction for 8 collections of plains rough fescue seed incubated for 400 degree days (base temperature equals $0^{\circ} \mathrm{C}$ ) at temperatures between 5 and $25^{\circ} \mathrm{C}$ in a gradient of osmotic potentials.

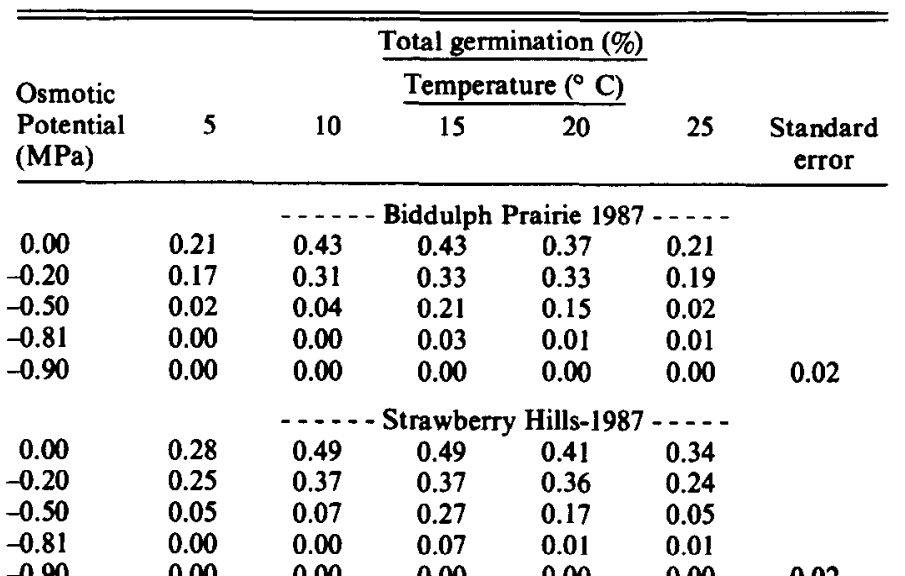

0.02

-..... Radisson-1987 .....

$\begin{array}{llllll}-0.20 & 0.28 & 0.51 & 0.52 & 0.46 & 0.33 \\ -0.50 & 0.26 & 0.35 & 0.37 & 0.40 & 0.28\end{array}$

$\begin{array}{llllll}-0.50 & 0.05 & 0.07 & 0.27 & 0.19 & 0.03\end{array}$

$\begin{array}{llllll}-0.81 & 0.00 & 0.00 & 0.06 & 0.02 & 0.01\end{array}$

$\begin{array}{llllll}-0.90 & 0.00 & 0.00 & 0.00 & 0.00 & 0.00\end{array}$

0.02

$\begin{array}{lllllll}0.00 & 0.31 & 0.51 & 0.50 & 0.46 & 0.35\end{array}$

$\begin{array}{llllll}-0.20 & 0.28 & 0.39 & 0.36 & 0.39 & 0.26\end{array}$

$\begin{array}{llllll}-0.50 & 0.12 & 0.06 & 0.30 & 0.23 & 0.05\end{array}$

$\begin{array}{llllll}-0.81 & 0.00 & 0.00 & 0.05 & 0.04 & 0.01\end{array}$

$0.00 \quad 0.67 \quad 0 . .-$. Cypress Hills-1988 $\ldots . .$.

$\begin{array}{rrrrrr}0.00 & 0.67 & 0.46 & 0.46 & 0.36 & 0.23 \\ -0.29 & 0.49 & 0.57 & 0.47 & 0.30 & 0.18\end{array}$

$\begin{array}{llllll}-0.68 & 0.05 & 0.32 & 0.24 & 0.08 & 0.03\end{array}$

$\begin{array}{llllll}-0.99 & 0.00 & 0.09 & 0.01 & 0.00 & 0.00\end{array}$

$\begin{array}{lllllll}-1.27 & 0.00 & 0.00 & 0.00 & 0.00 & 0.00 & 0.02\end{array}$

$\begin{array}{llllll}0.00 & 0.57 & 0.61 & 0.50 & 0.44 & 0.36\end{array}$

$\begin{array}{llllll}-0.29 & 0.23 & 0.56 & 0.40 & 0.31 & 0.22\end{array}$

$\begin{array}{llllll}-0.68 & 0.01 & 0.28 & 0.21 & 0.13 & 0.03\end{array}$

$\begin{array}{llllll}-0.99 & 0.00 & 0.03 & 0.00 & 0.00 & 0.00\end{array}$

$\begin{array}{llllll}-1.27 & 0.00 & 0.00 & 0.00 & 0.00 & 0.00\end{array}$

0.02

\begin{tabular}{rllllll}
0.00 & 0.42 & 0.57 & 0.42 & 0.37 & 0.25 & \\
-0.29 & 0.18 & 0.47 & 0.37 & 0.27 & 0.20 & \\
-0.68 & 0.01 & 0.22 & 0.17 & 0.07 & 0.02 & \\
-0.99 & 0.00 & 0.01 & 0.01 & 0.00 & 0.00 & \\
-1.27 & 0.00 & 0.00 & 0.00 & 0.00 & 0.00 & 0.02 \\
& & & & & \\
0.00 & 0.66 & 0.69 & 0.54 & 0.40 & 0.24 & \\
-0.29 & 0.32 & 0.57 & 0.34 & 0.32 & 0.25 & \\
-0.68 & 0.01 & 0.34 & 0.23 & 0.09 & 0.05 & \\
-0.99 & 0.00 & 0.04 & 0.00 & 0.00 & 0.00 & \\
-1.27 & 0.00 & 0.00 & 0.00 & 0.00 & 0.00 & 0.02 \\
\hline
\end{tabular}

nation was accounted for by osmotic potential, while $25-34 \%$ of the variation was partitioned into the influence of temperature regime and the interacting effects of temperature regime and osmotic potential.

\section{Discussion}

Temperature does not appear to place major restrictions on the germination of plains rough fescue; seeds can be expected to germinate over a wide thermal gradient. However, moisture availabil- 
Table 8. Regression equations for total germination and germination rate in ascending and descending temperature regimes for 8 collections of plains rough fescue seeds incubated for 600 degree days (base temperature equals $0^{\circ} \mathrm{C}$ ) in a gradient of osmotic potentials. Y is total germination (\%) or germination rate (\%/degree day) and $\mathrm{X}$ is osmotic potential (-MPa).

\begin{tabular}{|c|c|c|c|c|}
\hline \multirow{3}{*}{$\frac{\text { Collection }}{\text { and year }}$} & \multicolumn{3}{|c|}{ Temperature regime } & \multirow[b]{3}{*}{$\mathbf{R}^{2}$} \\
\hline & \multicolumn{2}{|l|}{ Ascending } & Descending & \\
\hline & Regression Equation & $\mathbf{R}^{2}$ & Regression Equation & \\
\hline \multicolumn{5}{|c|}{ - . . - Total germination (\%) $\ldots$} \\
\hline $\begin{array}{l}-1987 \text { - - - } \\
\text { Biddulph }\end{array}$ & $Y=82.5-5.4 X-38.7 X^{2}$ & 0.93 & $Y=72.2+61.2 X$ & 0.82 \\
\hline Allan Hills & $Y=92.8-60.0 X-104.7 X^{2}$ & 0.96 & $\mathrm{Y}=83.2+71.3 \mathrm{X}$ & 0.89 \\
\hline Strawberry Hills & $Y=89.4-28.4 X-68.7 X^{2}$ & 0.97 & $\mathrm{Y}=85.2+72.3 \mathrm{X}$ & 0.90 \\
\hline $\begin{array}{l}\text { Radisson } \\
-\ldots 1988-\ldots\end{array}$ & $Y=91.4-12.1 X-27.7 X^{2}$ & 0.95 & $Y=77.9+61.6 X$ & 0.77 \\
\hline Wood Mountain & $Y=71.9-41.4 X-111.5 X^{2}$ & 0.87 & $Y=80.2+72.7 X$ & 0.85 \\
\hline Cypress Hills & $Y=73.8-31.2 X-101.2 X^{2}$ & 0.91 & $Y=67.0+55.1 X$ & 0.76 \\
\hline Eagle Hills & $Y=86.5-53.7 X-156.7 X^{2}$ & 0.95 & $Y=88.0+80.5 X$ & 0.83 \\
\hline Sonningdale & $Y=70.6-73.2 X-171.2 X^{2}$ & 0.93 & $Y=69.3+61.1 X$ & 0.75 \\
\hline \multicolumn{5}{|c|}{ - - - - Germination Rate (\%/degree day) - - - - } \\
\hline - - $1987-\cdots$ & & & & \\
\hline Biddulph & $Y=0.43+0.34 X$ & 0.97 & $Y=0.21+0.24 X$ & 0.82 \\
\hline Allan Hills & $Y=0.56+0.44 X$ & 0.98 & $Y=0.31+0.28 X$ & 0.89 \\
\hline Strawberry Hills & $Y=0.51+0.38 X$ & 0.98 & $Y=0.32+0.28 X$ & 0.91 \\
\hline Wood Mountain & $Y=0.43+0.42 X$ & 0.90 & $Y=0.31+0.30 X$ & 0.85 \\
\hline Cypress Hills & $Y=0.46+0.45 X$ & 0.93 & $Y=0.24+0.22 X$ & 0.90 \\
\hline Eagle Hills & $Y=0.54+0.56 X$ & 0.93 & $Y=0.34+0.34 X$ & 0.90 \\
\hline Sonningdale & $Y=0.50+0.52 X$ & 0.91 & $Y=0.25+0.24 X$ & 0.87 \\
\hline
\end{tabular}

ity imposes severe limitations on its germination, especially at the extremes of the range of temperatures tested. This finding was highlighted by compartmentalizing variance of germination wherein moisture stress accounted for the largest percentage of total variation.

Plants possessing seeds with exacting requirements for germination can establish more successfully than those with few restrictions (Hegarty 1978). However, in an environment with changing moisture conditions the opportunities for germination may be reduced for seeds with specific moisture requirements. If moisture stress is low, seeds of plains rough fescue can germinate over a broad range of temperatures; but water stress overrides temperature influences, and narrows the conditions where germination will occur. This response presumably reflects an adaptive strategy because plains rough fescue is generally restricted to habitats with cooler and moister conditions than those of the Mixed Prairie of the northern Great Plains (Coupland and Brayshaw 1953, Ayyad and Dix 1964). Such an adaptation protects against germination under conditions of transient or low soil moisture, limiting most germination to periods with protracted conditions of high soil moisture.

These data clearly illustrated that germination is potentially high when seedbed temperatures are moderate. That maximum germination occurred most frequently at $15 / 15$ and $20 / 20^{\circ} \mathrm{C}$, and seeds germinated over the broadest range of osmotic potentials at temperatures between 10 and $20^{\circ} \mathrm{C}$, is strong evidence that moderate temperatures are optimum for germination. Similar results were reported for rough fescue, with maximum germination occurring in 6 of the same 55 regimes, with a frequency of $100 \%$ at $15 / 20^{\circ}$ C (Young and Evans 1982). Johnston (1961) reported that total germination for rough fescue was highest at 13,18 , and $24^{\circ} \mathrm{C}$ and it was lowest at $30^{\circ} \mathrm{C}$.

This range of optimal germination temperatures is similar to that in the soils of the Fescue Prairie during July and August (Johnston et al. 1971) when most seeds of plains rough fescue shatter from plants. Seeds of plains rough fescue apparently do not have an after-ripening requirement, since preliminary tests showed germination of freshly harvested seeds averaged $81 \%$ and $87 \%$ at $10^{\circ} \mathrm{C}$ and $20^{\circ} \mathrm{C}$, respectively (Romo, unpublished data). Therefore, provided seeds reach safe sites, they can germinate immediately upon ripening.

Exposure to the descending temperature regime and water stress reduced germination, and this reduction was not overcome by exposure to progressively lower temperatures. Relatively warm soil temperatures and water deficits are usually simultaneous events in Fescue Prairie. Providing seed mortality does not occur, dormancy induced by warm temperatures and water stress may act to preserve a portion of the seedbank for germination at a later date. However, a seedbank for the closely allied rough fescue is negligible (Johnston 1961). Induction of dormancy under these conditions may also serve to block germination that would otherwise predispose seedlings to temperature and moisture conditions that may not be conducive for their growth and survival.

With increasing temperatures, the restrictions imposed by water stress were not as strong as those imposed by declining temperatures. In Fescue Prairie, an increasing temperature regime is characteristic of spring. In spring, soils usually have high moisture content because of moisture recharge from snowmelt and early precipitation. Increasing temperatures also provide conditions favorable for growth of seedlings (Smoliak and Johnston 1968). However, the germination response observed under increasing temperatures in the present study may be modified by overwinter chilling of seeds. Stratification of plains rough fescue seeds at $2^{\circ} \mathrm{C}$ reduces germination under an ascending temperature regime (Romo, unpublished data).

The basic biological limitation of sexual reproduction in plains rough fescue is its infrequent production of seed. Exact reasons for this sporadic flowering are not known (Johnston and MacDonald 1967). Since plains rough fescue is a long-lived and weakly rhizomatous plant, high rates of regeneration from seed may not be necessary for maintenance of populations (Grime 1979). This proposition assumes that asexual reproduction is not being limited 
and mortality rates are not altered. However, most remaining stands of plains rough fescue are severely depleted because of imprudent grazing management. In these depleted stands vegetative expansion is reduced, and the importance of regeneration from seed is elevated compared to pristine stands.

Complicating this issue of sexual regeneration is the fact that microenvironmental conditions of most Fescue Prairie has been substantially transformed by grazing. Temperature extremes of the soils are greatest and soil moisture is reduced (Johnston 1961, Johnston et al. 1971). Cold and warm temperatures, and widely fluctuating temperatures, greatly reduced germination of this grass, and water stress is a major determinant of germination. Thus, the combination of high seed production and conditions favorable for germination and growth are probably a rare sequence of events that are made more unlikely by improper grazing activities.

\section{Management Implications}

Plains rough fescue has the ability to germinate over a broad range of temperatures, but severe restrictions are imposed by reduced moisture availability. These characteristics together with the fact that seeds germinated more rapidly and in higher numbers over a wider range of osmotic potentials when temperatures were increased from low to high temperatures suggest that this species should be planted in early spring when seedbed temperatures are increasing.

\section{Literature Cited}

Ayyad, M.A., and R.L. Dix. 1964. An analysis of a vegetation-microenvironmental complex on prairie slopes in Saskatchewan. Ecol. Monogr. 34:421-442.

Coupland, R.T. 1961. A reconsideration of grassland classification in the Northern Great Plains of North America. J. Ecol. 49:135-167.

Coupland, R.T., and T.C. Brayshaw. 1953. The Fescue grassland in Saskatchewan. Ecology 34:386-405.

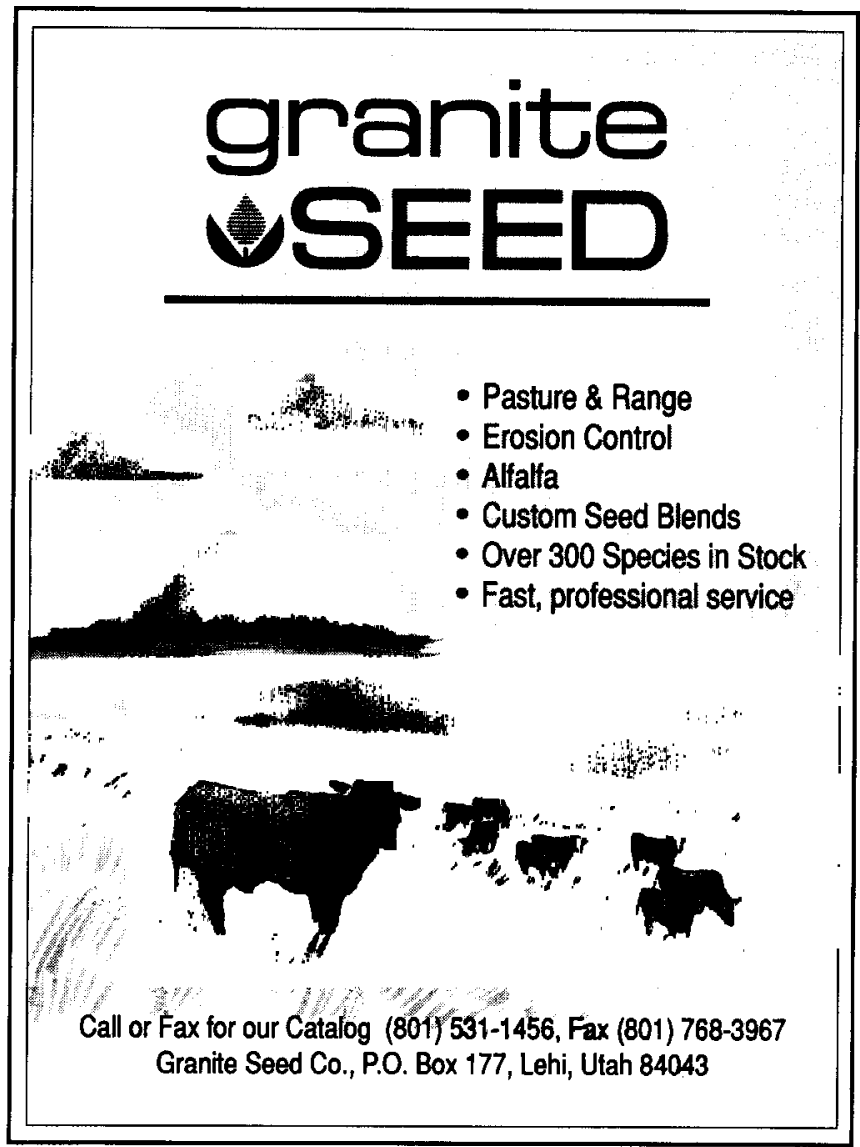

Evans, R.A., D.A. Easi, D.N. Book, and J.A. Young. 1982. Quadratic response surface analysis of seed germination trials. Weed Sci. 30:411-416. Grime, J.P. 1979. Plant strategies and vegetation processes. John Wiley and Sons. New York.

Harms, V.L. 1985. A reconsideration of the nomenclature and taxonomy of the Festuca altaica complex (Poaceae) in North America. Madrono 32:1-10.

Hegarty, T.W. 1978. The physiology of seed hydration and dehydration, and the relation between water stress and the control of germination: a review. Plant, Cell and Environ. 1:101-119.

Johnson, I.R., and J.H.M. Thornley. 1985. Temperature dependence of plant and crop processes. Ann. Bot. 55:1-24.

Johnston, A. 1961. Comparison of lightly grazed and ungrazed range in the fescue grassland of southwestern Alberta. Can. J. Plant Sci. 41:615-622.

Johnston, A., and M.D. MacDonald. 1967. Floral initiation and seed production in Festuca scabrella Torr. Can. J. Plant Sci. 47:577-583.

Johnston, A., J.F. Dormaar, and S. Smoliak. 1971. Long-term grazing effects on Fescue Grassland soils. J. Range Manage. 24:185-188.

Maguire, J.D. 1962. Speed of germination-aid in selection and evaluation of seedling emergence and vigor. Crop Sci. 2:176-177.

Smoliak, S., and A. Johnston. 1968. Germination and early root growth of grasses at four root-zone temperatures. Can. J. Plant Sci. 48:119-127.

Snedecor, G.W., and W.C. Cochran. 1980. Statistical methods. The lowa State University Press, Ames.

Steel, R.G.D., and J.H. Torric. 1980. Principles and procedures of statistics. McGraw-Hill Book Co., New York.

Toynbee, K. 1987. Prolific flowering year for plains rough fescue at the Kernen Prairie. Bluejay 45:142-143.

Young, J.A., and R.A. Evans. 1982. Temperature profiles for germination of cool season range grasses. USDA Agr. Res. Serv. Pub. ARR-W-27.

Statement of Ownership, Management, and Circulation (Act. of August 12, 1970, Sec. 3685, Title 39, United States Code)

1. Title of Publication: Journal of Range Management

2. Date of Filing: September 28, 1990

3. Frequency of Issue: Bimonthly

4. Location of Office of Publication: 1839 York Street, Denver, Colo. 80206

5. Location of General Business Office: Same

6. Name and Address of:

Publisher: Society for Range Management, 1839 York Street, Denver, Colo. 80206

Editor: Gary Frasier, USDA-ARS, Crops Research Laboratory, 1701 Center Ave, Fort Collins, Colo. 80526

Managing Editor: Peter V. Jackson III, 1839 York Street, Denver, Colo. 80206

7. Owner: Society for Range Management, 1839 York Street, Denver, Colo. 80206

8. Known Bondholders, Mortgagees, etc.: Wyatt Company, 1850 M. Street NW \#700, Washington, DC 20036

9. For Completion by Nonprofit Organizations Authorized to Mail at Special Rates: The purpose, function, and nonprofit status of this organization and the exempt status for Federal income tax purposes have not changed during preceding 12 months.

10. Extent and Nature of Circulation
A. Total copies printed
B. Paid Circulation
1. Dealers, counter sales
2. Mail subscriptions
C. Total paid circulation
D. Free distribution
E. Total distribution
F. Copies not distributed
G. Total

Actual for

Avg. for issue nearest

12 months filing date

$5,117 \quad 5,665$

$\begin{array}{cc}0 & 0 \\ 5,103 & 5,275 \\ 5,103 & 5,275 \\ 14 & 14 \\ 5,117 & 5,289 \\ 716 & 376 \\ 5,833 & 5,665\end{array}$

I certify that the statements made by me above are correct and complete.-Peter V. Jackson, Managing Editor. 